\title{
ANALYTICAL IDENTIFICATION OF HISTORICAL WRITING INKS - A NEW METHODOLOGICAL APPROACH
}

\author{
J. Senvaitienè, A. Beganskienè, L. Salickaitė-Bunikienè, and A. Kareiva \\ Faculty of Chemistry, Vilnius University, Naugarduko 24, LT-03225 Vilnius, Lithuania \\ E-mail: aivaras.kareiva@chf.vu.lt
}

Received 5 December 2005

\begin{abstract}
A novel methodological approach has been developed for the qualitative determination of nature of historical writing inks. The identification of unknown historical writing ink was performed using FTIR, UV and visible spectroscopies and capillary electrophoresis. The infrared spectra of all samples were recorded using two different techniques (KBr pellet and $\mathrm{ZnSe}$ cell). The $\mathrm{KBr}$ method was used for the characterization of ink samples evaporated to dryness, while ZnSe cell techniques were used for the analysis of ink aqueous solutions or suspensions. It was demonstrated that the $\mathrm{KBr}$ method could be used for the determination of nature of the historical writing ink sample, however, the application of ZnSe cell technique for the identification of specific features was problematic. Characterization by UV and visible spectroscopies and capillary electrophoresis also revealed the characteristic features in the ink samples providing a possibility to determine the identity of historical writing ink regarding its chemical composition.
\end{abstract}

Keywords: historical writing inks, analytical characterization, qualitative analysis, FTIR spectroscopy, UV and visible spectroscopies, capillary electrophoresis

PACS: 82.80.-d, 81.05.-d

\section{Introduction}

Important historical documents, manuscripts, maps in libraries and archives suffer very serious damage as a result of the destructive effects of different kind of inks [1-3]. The reasons for this destruction are not fully understood yet [4-9]. The desire to protect the paper in ancient books and archival materials from degradation necessitates the development of effective treatment methods $[10,11]$. However, hundreds of recipes for ink have been published over centuries [12-14]. A great variety of ink recipes and the variety of visual aspects of manuscripts suggest that many side effects could occur and contribute to different aspects of paper degradation [15-20].

For the fabrication of protective coatings for differently inked paper samples the approximate chemical composition of writing ink should be known to avoid the destructive effects of coatings on the writing inks $[21,22]$. Therefore, the importance of chemical composition of historical inks in the development of new conservation and restoration techniques requires their fast and accurate identification. Several analytical techniques such as atomic absorption spectrometry, thermal analysis, potentiometry, high-performance liquid chro- matography, gas chromatography coupled with mass spectrometry, scanning electron microscopy and energy dispersive X-ray microanalysis, reflectance spectrometry, proton-induced X-ray photoelectron spectroscopy, X-ray fluorescence spectrometry, and other spectroscopic techniques [23-33] have been applied for determining the constituents of the inks. Most of these techniques are complex and generally require several time-consuming analytical steps. In this paper we report a new methodological approach for a rapid qualitative identification of the unknown historical writing ink sample using FTIR, UV and visible spectroscopies, and capillary electrophoresis.

\section{Experimental}

Different historical writing inks such as Pfalz ink from red wine, iron-gall ink, copper-gall ink, logwood tree ink, and others were selected as standard ink samples [34]. The choice of these inks was based upon their maximum prevalence and availability. Namely, these ancient ink recipes fall into the most popular categories: (a) inks colours of which originate from the natural dyes; (b) iron (copper)-gall inks prepared using natural products from the oak galls; (c) metal sulphate 
inks additionally containing natural dyes; (d) iron-gall inks prepared using gallic and tannic acids. Analytical grade reagents and distilled water were used for the preparation of inks. The unknown ink to be analysed was kindly provided by Pelikan Inks.

The writing ink samples were prepared using following recipes:

- Ink $1 ; 16 \mathrm{ml}$ of cold distilled water and $1 \mathrm{ml}$ of $10 \%$ acetic acid were added to the powdered oak galls $(1 \mathrm{~g})$, iron (II) sulphate $(0.53 \mathrm{~g})$, and gum arabic $(0.53 \mathrm{~g})$. After careful grinding the mixture was stored for 8 weeks with intermediate mixing in a slightly covered vessel and filtered.

- Ink 2; $100 \mathrm{ml}$ of distilled water, $0.7 \mathrm{ml}$ of $10 \%$ hydrochloric acid, $0.77 \mathrm{~g}$ of gallic acid, $1.0 \mathrm{~g}$ of gum arabic, $2.34 \mathrm{~g}$ of tannin, $0.1 \mathrm{~g}$ of phenol, and $3.0 \mathrm{~g}$ of iron (II) sulphate were carefully mixed. The obtained mixture was filtered.

- Ink 3;100 ml of red wine was carefully mixed with $5 \mathrm{~g}$ of powdered cherry gum and $4 \mathrm{~g}$ of soot. The obtained mixture was stored for 2 weeks in a closed vessel with intermediate (daily) shaking.

- Ink 4; $100 \mathrm{ml}$ of distilled water, $20 \mathrm{~g}$ of logwood tree, $1.5 \mathrm{~g}$ of gum arabic, and $0.1 \mathrm{~g}$ of chromium alum were carefully mixed. The obtained mixture was filtered.

- Ink 5; $66.8 \mathrm{ml}$ of distilled water was mixed with $7.688 \mathrm{~g}$ of powdered oak galls and mixture was stored for 4 days. To this $2.528 \mathrm{~g}$ of copper (II) sulphate, $0.2 \mathrm{~g}$ of sodium chloride, $2 \mathrm{ml}$ of $10 \%$ acetic acid, and $0.318 \mathrm{~g}$ of alum were added. The obtained mixture was stored for 2 weeks with intermediate mixing and filtered.

The ink samples were characterized by infrared spectroscopy using a Perkin-Elmer FTIR Spectrum BX II spectrometer. The samples were slowly evaporated to dryness and mixed $(\sim 1.0 \%)$ with dried $\mathrm{KBr}$ and pressed into pellets. FTIR spectra for aqueous solutions of inks using ZnSe cell ("Altechna", Lithuania) were also recorded. Thickness of the $\mathrm{ZnSe}$ cell is $3 \mathrm{~mm}$. The number of spectra averaged was 5. After each measurement the $\mathrm{ZnSe}$ cell was cleaned with ethanol. The following instrumental settings were used: transmission (\%), range from 3700 to $400 \mathrm{~cm}^{-1}, 20$ scan, resolution $\pm 4 \mathrm{~cm}^{-1}$, gain 1 , scan speed $0.3 \mathrm{~cm} / \mathrm{s}$, temperature $25^{\circ} \mathrm{C}$. The ink samples were also characterized by UV and visible spectroscopies using PerkinElmer FTIR Spectrum Lambda 20 and SF-26 spectrophotometers, respectively. Capillary electrophoretic

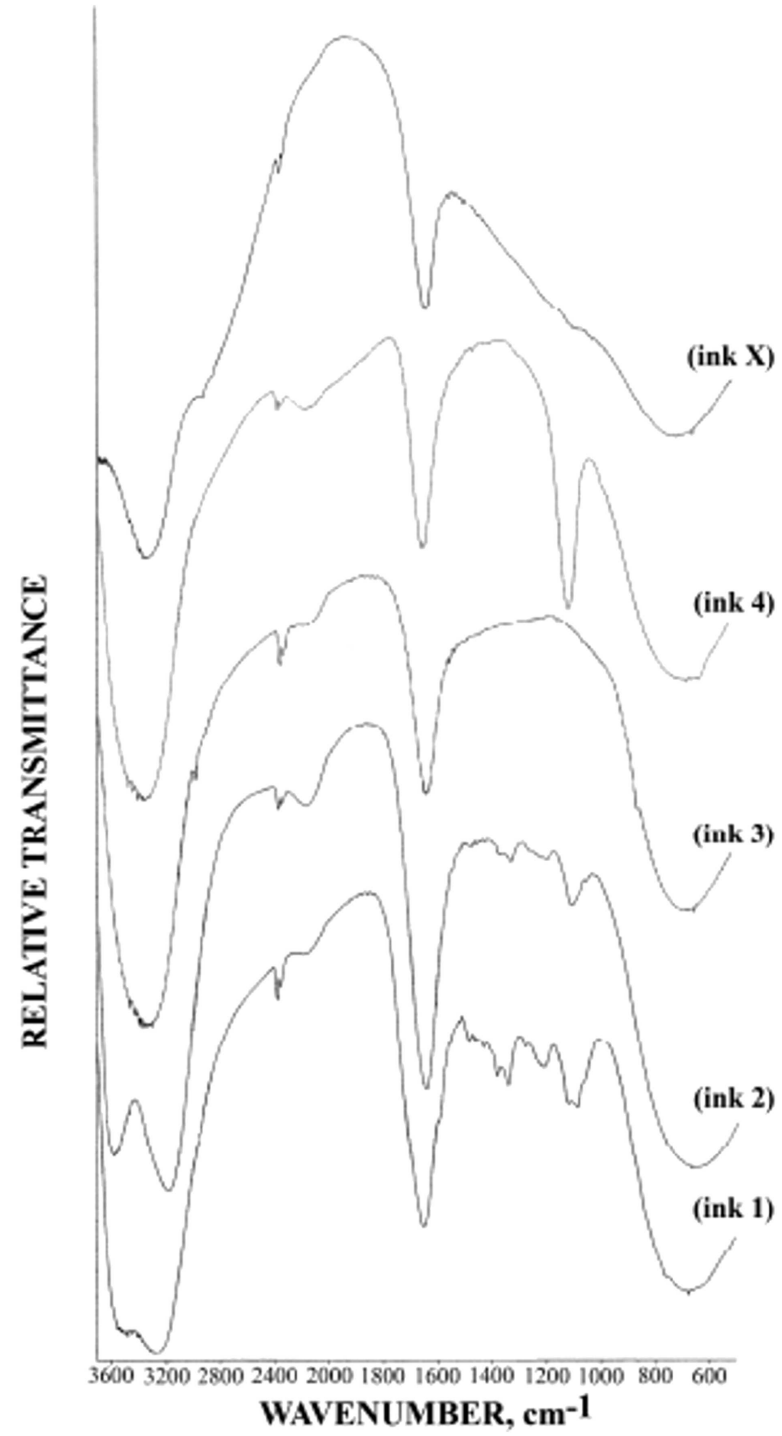

Fig. 1. The FTIR spectra of aqueous solutions of ink samples recorded on $\mathrm{ZnSe}$ cell.

analysis was performed on a $\mathrm{P} / \mathrm{ACE} 2100$ apparatus (Beckman Instruments) equipped with a UV detector with wavelength filters (200, 214, 230, and $254 \mathrm{~nm})$. Fused silica capillary (Polymicro Technology, Phoenix, AZ, USA) of $75 \mu \mathrm{m} \mathrm{I}$. D. and $57 \mathrm{~cm}$ total length $(50 \mathrm{~cm}$ to the detector) was used. Samples were introduced in the hydrodynamic mode by overpressure $\left(3.43 \cdot 10^{3} \mathrm{~Pa}\right)$. A pH meter Mettler-Toledo MP220 was employed for measuring $\mathrm{pH}$ of inks in the aqueous phase.

\section{Results and discussion}

The infrared spectra of ink samples were recorded using two different techniques: $\mathrm{KBr}$ pellet and $\mathrm{ZnSe}$ cell. The FTIR spectra for aqueous solutions of ink samples using ZnSe cell are shown in Fig. 1. The figure 


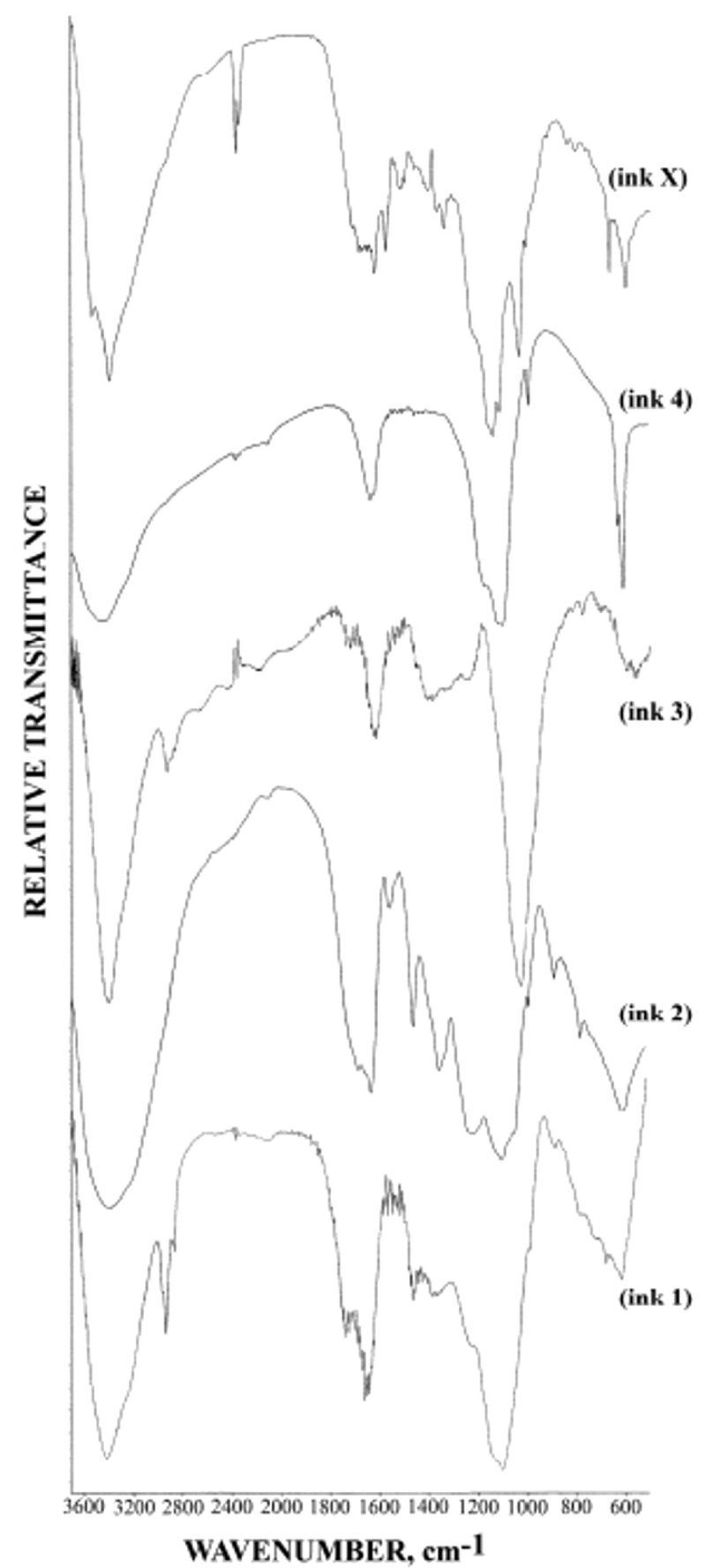

Fig. 2. The FTIR spectra of ink samples recorded as $\mathrm{KBr}$ pellets.

contains five FTIR spectra of different inks: iron-gall ink prepared using natural products from the oak galls (ink 1), iron gall ink prepared using gallic and tannic acids (ink 2), inks colours of which originate from the natural dyes (inks 3 and 4), and ink provided by Pelikan Inks with unknown chemical composition (ink $X$ ).

As seen from Fig. 1, all five FTIR spectra recorded using $\mathrm{ZnSe}$ cell are almost identical. The spectra contain two broad bands in the ranges $\sim 3700-2800 \mathrm{~cm}^{-1}$ and $\sim 900-500 \mathrm{~cm}^{-1}$, and a sharper strong band at

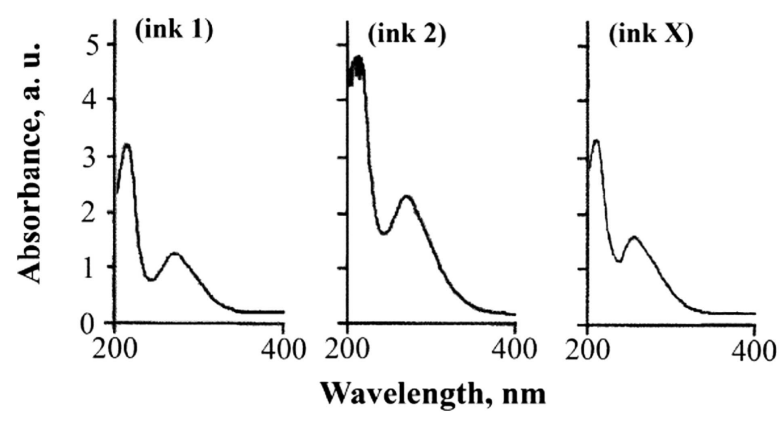

Fig. 3. UV spectra of different ink samples.

$1650-1640 \mathrm{~cm}^{-1}$ attributable to $\mathrm{OH}$ vibrations in water molecule. In the FTIR spectrum of ink $X$, as is observed in the spectra of inks 1 and 2 (see Fig. 1), the splitting of the strong band at $3700-2800 \mathrm{~cm}^{-1}$ originating possibly from water of crystallization could be observed. However, the intensities of these two bands in the spectrum of ink $X$ are different compared with those of inks 1 and 2. Can this suggest that ink $X$ belongs to the group of metal-gall inks? Multiple absorptions in the range from $1450 \mathrm{~cm}^{-1}$ to $1180 \mathrm{~cm}^{-1}$ attributable to the gallic acid or tannin are clearly presented in the spectra of inks 1 and 2 . These absorption peaks, however, are not very well resolved in the FTIR spectrum of ink $X$. The well-resolved bands around $1108 \mathrm{~cm}^{-1}$ for the inks 1,2 , and 4 indicate the existence of sulphate in the composition of inks. Besides, the negligible splitting of the strong band at $3700-2800 \mathrm{~cm}^{-1}$ could be observed and in the infrared spectrum of ink 3. Therefore, we can conclude that the application of $\mathrm{ZnSe}$ cell technique for the identification of specific features of writing inks is problematic.

The FTIR spectra of the same five ink samples pressed into $\mathrm{KBr}$ pellets are presented in Fig. 2. Broad absorptions in all spectra around $3700-3000 \mathrm{~cm}^{-1}$ and $1670-1620 \mathrm{~cm}^{-1}$ indicate the presence of adsorbed water in the samples [34]. The bands at around $2360-2340 \mathrm{~cm}^{-1}$ presented in the spectra belong to carbon dioxide adsorbed from the atmosphere. However, according to the origin of the bands, it is clearly seen that some of investigated inks are different regarding their chemical composition. It is evident that the unknown ink $X$ cannot be attributed to the inks colours of which originate from the natural dyes. The distinctive features observed in the FTIR spectrum of ink $X$ presented in Fig. 2 are very similar to those present in the FTIR spectra of iron-gall inks prepared using natural products from the oak galls, or using gallic and tannic acids. The characteristic absorption bands due to the stretch vibrations in $\mathrm{SO}_{4}{ }^{2-}$ (strong 
in the ranges $1120-1040 \mathrm{~cm}^{-1}$ and $645-570 \mathrm{~cm}^{-1}$, and weak at $976 \mathrm{~cm}^{-1}$ ) and in $\mathrm{CO}-\mathrm{OH}$ (strong between $1700-1650 \mathrm{~cm}^{-1}$ and $1350-1340 \mathrm{~cm}^{-1}$ and medium between 950 and $825 \mathrm{~cm}^{-1}$ ) are clearly present in the FTIR spectrum of ink $X$. These features are also evident in the FTIR spectra of iron gall inks. The FTIR spectrum of ink $X$, analogically as in FTIR spectra of inks 1 and 2, also shows bands at $2925 \mathrm{~cm}^{-1}, 1450 \mathrm{~cm}^{-1}$, and $1220 \mathrm{~cm}^{-1}$, which probably originate from gum arabic [34]. FTIR spectroscopic evaluation of ink samples evaporated to dryness provides a possibility to identify roughly the historical inks regarding their chemical composition. According to the observed specific features in the FTIR spectrum, the investigated unknown ink can be attributed to the category of metal-gall inks containing metal sulphates as ingredients. The similarity of the characteristic absorptions from the specific constituents in the FTIR spectra allows us to predict that the investigated ink $X$ belongs to the category of iron gall inks prepared using natural products from the oak galls. However, such observation is fairly speculative, since the FTIR spectra of iron gall inks prepared using natural products from the oak galls and iron prepared using gallic and tannic acids show insufficient difference.

The UV spectra of inks 1,2 , and $X$ are presented in Fig. 3. The distinctive features observed in the UV spectrum of iron gall inks prepared with powdered oak galls (ink 1) are two intensive absorption bands at $215 \mathrm{~nm}$ (sharp) and $269 \mathrm{~nm}$ (broad). Much more intensive absorptions at the same wavelengths are observed in the UV spectrum of iron gall inks prepared with gallic acid instead of the natural products from the powdered oak galls (ink 2). These absorptions are typical absorptions of $\mathrm{Fe}^{2+}$ complex with gallic acid. A close similarity between UV spectra of inks $l$ and $X$ (see Fig. 3) could be easily identified. Thus, from FTIR and UV measurements we can conclude that unknown ink $X$ belongs to the category of iron gall inks prepared using natural products from the oak galls. Figure 4 represents the UV spectrum of well-known ancient coppergall ink prepared using natural products from the oak galls (ink 5). Apparently this spectrum is very similar to those of inks 1 and $X$. This is not surprising, taking into account the chemical composition of ink 5. So, the question whether the ink $X$ belongs to the category of iron- or copper-gall inks still should be answered.

In addition, a capillary electrophoretic method was applied for the analysis of aqueous solutions of ink $X$ and metal-gall ink samples. The electropherograms of this group of inks are shown in Fig. 5. The electro-

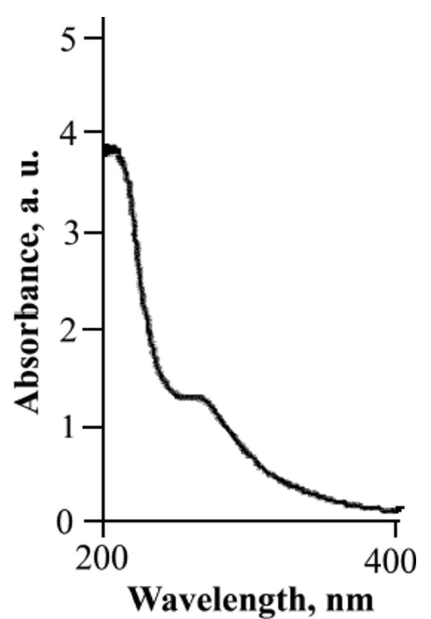

Fig. 4. UV spectrum of ink 5.

pherograms are similar having the main peaks in the range of 4.6-6.3 min. However, the sufficient difference could also be easily detected. As seen from Fig. 5, the electropherogram of ink $X$ contains two very intensive peaks together with several less intensive other peaks with sufficient separation selectivity. The electropherogram of ink 5 , however, contains only one very well resolved characteristic peak at $\sim 5.7 \mathrm{~min}$ and two satellites. Apparently, the electropherogram of ink $X$ contains more common features to that of iron-gall ink. Thus, we can conclude that historical metal-gall inks could be easily identified using a capillary electrophoretic technique.

The electropherograms of iron and copper gall inks prepared using natural products from the oak galls show sufficient difference. However, additionally the optical spectra in visible region over the range of $400-750 \mathrm{~nm}$ for aqueous solutions of the same ink samples (ink 1, 5, and $X$ ) were compared (Fig. 6). Interestingly, the spectra of the iron gall (ink 1) and unknown (ink $X$ ) inks are nearly the same. These spectra show only one very broad absorption band with $\lambda_{\max } \approx$ $590-610 \mathrm{~nm}$. However, it is evident that visible spectrum of the copper gall ink sample (ink 5) could be easily distinguished from those of iron gall inks. The spectrum of copper gall ink contains a shoulder at $\lambda_{\max } \approx$ $400-425 \mathrm{~nm}$, and in contrast to the iron gall inks does not show any absorption in the region of wavelengths of $590-610 \mathrm{~nm}$. The similarity of electronic spectra observed for ink $X$ and ink 1 once again confirms that the investigated unknown ink $X$ could be identified as iron-gall ink prepared using natural products from the oak galls. In conclusion, the results obtained demonstrate that a unique methodological approach has been developed for the qualitative determination of nature of historical writing inks. Such analytical characterization 

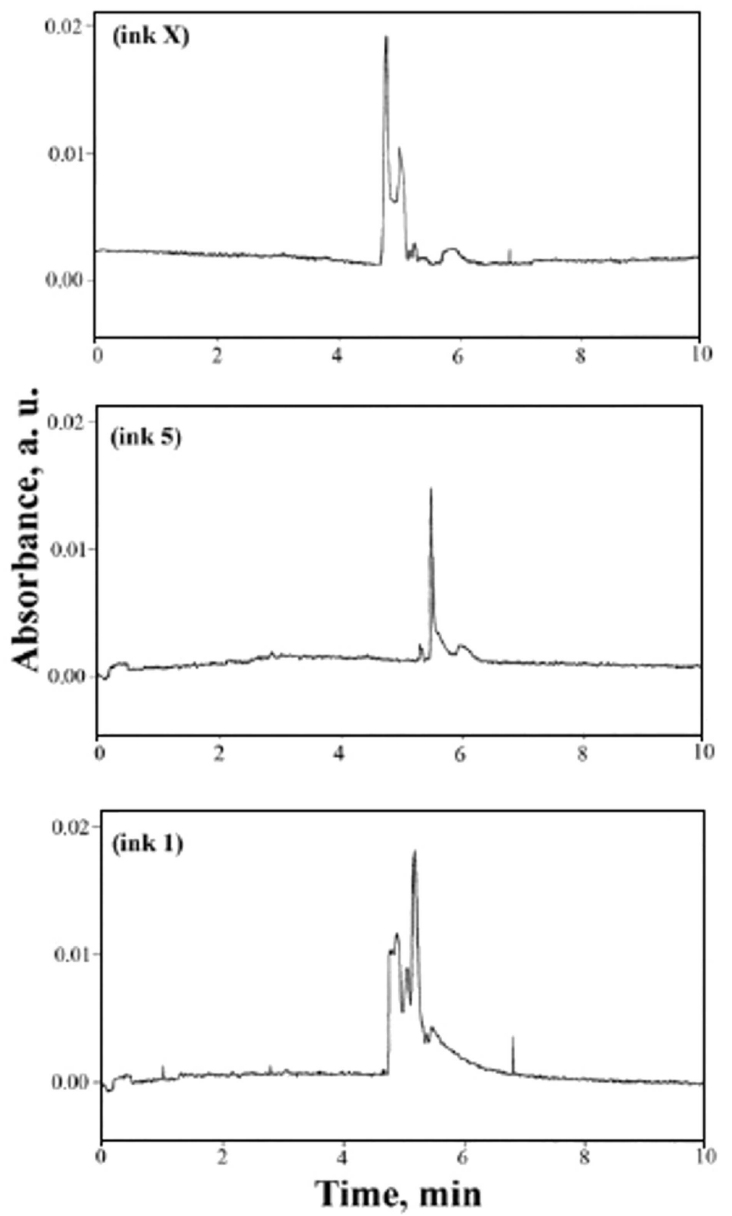

Fig. 5. Electropherograms of different ink samples.

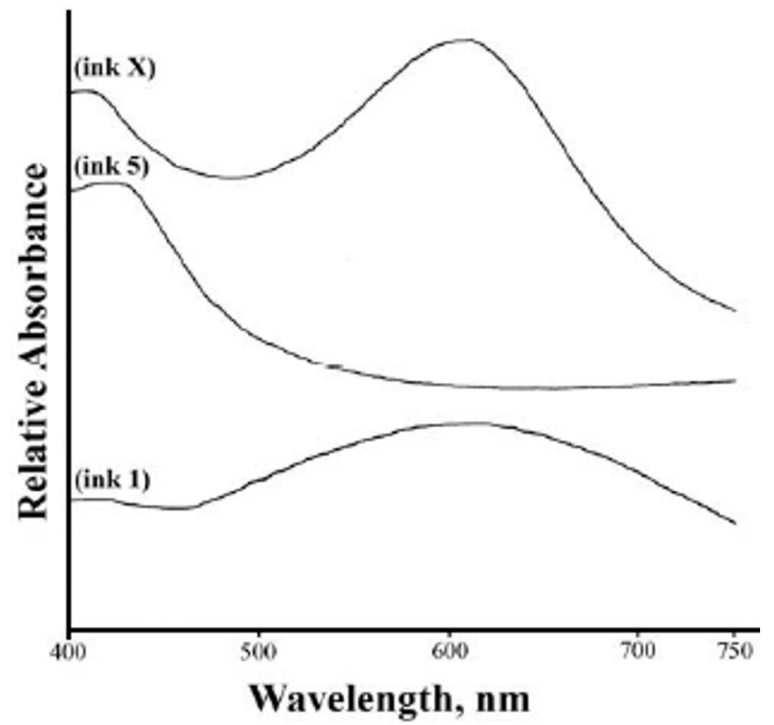

Fig. 6. Electronic spectra of different ink samples.

of unknown writing inks undoubtedly could be useful for the preparation of new methods of conservation and restoration of historical paper documents.

\section{Conclusions}

The present study shows that FTIR, UV, and visible spectroscopies and capillary electrophoresis may provide very important information on the chemical composition of historical writing inks. The observed characteristic features in the FTIR spectra allow attributing the investigated inks to two categories: metalgall inks and inks colours of which originate from the natural dyes. From the UV measurements the metalgall inks prepared using natural products from the oak galls or prepared using gallic and tannic acids could be easily distinguished. Evidently, using capillary electrophoretic technique and visible spectroscopy the iron and copper gall inks could be identified. Finally, a novel methodological approach has been developed for the qualitative determination of nature of unknown historical writing inks. The results obtained demonstrate that the investigated unknown ink belongs to the category of iron-gall inks prepared using natural products from the oak galls.

\section{Acknowledgements}

We would like to thank professors A. Padarauskas and S. Tautkus (Department of Analytical and Environmental Chemistry, Vilnius University) for helpful discussions.

\section{References}

[1] A.N. Macinnes and A.R. Barron, Spectroscopic evaluation of the efficacy of two mass deacidification processes of paper, J. Mater. Chem. 2, 1049-1056 (1992).

[2] S. Fairbrass, Sticky problems for conservators of works of art on paper, Int. J. Adhes. Adhesiv. 15, 115-120 (1995).

[3] B. Havlinova, D. Babiakova, V. Brezova, M. Durovic, M. Novotna, and F. Belanyi, The stability of offset inks on paper upon ageing, Dyes Pigm. 54, 173-188 (2002).

[4] I. Espadaler, M.C. Sistach, M. Cortina, E. Eljarrat, R. Alcaraz, J. Cabanas, and J. Rivera, Organic and inorganic components of manuscript inks, Anal. Quimica 91, 359-364 (1995).

[5] P. Calvini and A. Gorassini, The degrading action of iron and copper on paper. A FTIR-deconvolution analysis, Restaurator 23, 205-221 (2002).

[6] P. Rudolph, F.J. Ligterink, J.L. Pedersoli Jr., M. van Bommel, J. Bos, H.A. Awiz, J.B.G.A. Havermans, H. Scholten, D. Schipper, and W. Kautek, Characterization of laser-treated paper, Appl. Phys. A 79, 181186 (2004). 
[7] V. Rouchon-Quillet, C. Remazeilles, J. Bernard, A. Wattiaux, and L. Fournes, The impact of gallic acid on iron gall ink corrosion, Appl. Phys. A 79, 389-392 (2004).

[8] B. Wagner, E. Bulska, B. Stahl, M. Heck, and H.M. Ortner, Analysis of $\mathrm{Fe}$ valence states in iron-gall inks from XVIth century manuscripts by Fe-57 Mossbauer spectroscopy, Anal. Chim. Acta 527, 195-201 (2004).

[9] G. Banik, Mass deacidification technology in Germany and its quality control, Restaurator 26, 63-75 (2005).

[10] T. Edwards, UK paper conservation courses: An overview, J. Soc. Archiv. 20, 49-60 (1999).

[11] J.D. Mackenzie and E.P. Bescher, Physical properties of sol-gel coatings, J. Sol-Gel Sci. Technol. 19, 23-29 (2000).

[12] J.G. Neevel, Phytate: A potential conservation agent for the treatment of ink corrosion caused by iron gall inks, Restaurator 16, 143-160 (1995).

[13] J. Thompson, Manuscript Inks (The Caber Press, Portland, Oregon, 1996).

[14] C. Krekel, The chemistry of historical iron gall inks (1): Understanding the chemistry of writing inks used to prepare historical documents, Int. J. Foren. Docum. Exam. 12, 54-60 (1999).

[15] S. Margutti, G. Conio, P. Calvini, and E. Pedemonte, Hydrolytic and oxidative degradation of paper, Restaurator 22, 67-83 (2001).

[16] L.M. Proniewicz, C. Paluszkiewicz, A. WeseluchaBirczynska, H. Majcherczyk, A. Baranski, and A. Konieczna, FT-IR and FT-Raman study of hydrothermally degradated cellulose, J. Mol. Struct. 596, 163-169 (2001)

[17] J.R. Mansfield, M. Attas, C. Majzels, E. Cloutis, C. Collins, and H.H. Mantsch, Near infrared spectroscopy reflectance imaging: A new tool in art conservation, Vibr. Spectr. 28, 59-66 (2002).

[18] J. Kiuberis, R. Kazlauskas, L. Grabauskaite, S. Tautkus, and A. Kareiva, Scanning electron microscopy - a powerful tool for the characterization of materials. 2. Modified sol-gel chemistry approach to the conservation of paper, Environmental and Chem. Phys. 25, 81-85 (2003).

[19] J. Kolar, M. Strlic, M. Budnar, J. Malesic, V.S. Selih, and J. Simcic, Stabilisation of corrosive iron gall inks, Acta Chim. Slov. 50, 763-770 (2003).

[20] A. Zappala and C. De Stefani, Evaluation of the effectiveness of stabilization methods - Treatments by deacidification, trehalose, phytates on iron gall inks, Restaurator 26, 36-43 (2005).

[21] J. Senvaitiene, I. Pakutinskiene, A. Beganskiene, S. Tautkus, R. Kazlauskas, and A. Kareiva, Destructive effects of paper conservation procedure on the writing iron gall ink - evidence from transmetalation reaction, Polish J. Chem. 79, 1575-1583 (2005).
[22] J. Kiuberis, S. Tautkus, R. Kazlauskas, I. Pakutinskiene, and A. Kareiva, Protective coating for paper: New development and analytical characterization, J. Cult. Herit. 6, 245-251 (2005).

[23] P. Arpino, J.-P. Moreau, C. Oruezabal, and F. Flieder, Gas chromatographic-mass spectrometric analysis of tannin hydrolysates from the ink of ancient manuscripts (XIth to XVIth century), J. Chromat. A 134, 433-439 (1977).

[24] V. Mosini, P. Calvini, G. Mattogno, and G. Righini, Derivative infrared spectroscopy and electron spectroscopy for chemical analysis of ancient paper documents, Cellul. Chem. Technol. 24, 263-272 (1990).

[25] P. Calvini, E. Franceschi, and D. Palazzi, Artificially induced slow-fire in sized papers: FTIR, TG, DTA and SEM analyses, Sci. Technol. Cult. Herit. 5, 1-11 (1996).

[26] P.J. Gibbs, K.R. Seddon, N.M. Brovenko, Y.A. Petrosyan, and M. Barnard, Analysis of ancient dyed Chinese papers by high-performance liquid chromatography, Anal. Chem. 69, 1965-1969 (1997).

[27] G. Righini, A.L. Segre, G. Mattogno, C. Federici, and P.F. Munafo, An X-ray photoelectron spectroscopic study of ancient paper and its deterioration, Naturwissenschaften 85, 171-175 (1998).

[28] B. Wagner, E. Bulska, A. Hulanicki, M. Heck, and H.M. Ortner, Topochemical investigation of ancient manuscripts, Fresenius J. Anal. Chem. 369, 674-679 (2001).

[29] E. Bulska, B. Wagner, and M.G. Sawicki, Investigation of complexation and solid-liquid extraction of iron from paper by UV/VIS and atomic absorption spectrometry, Microchim. Acta 136, 61-66 (2001).

[30] O. Hahn, W. Malzer, B. Kanngiesser, and B. Beckhoff, Characterization of iron-gall inks in historical manuscripts and music compositions using X-ray fluorescence spectrometry, X-ray Spectrom. 33, 234-239 (2004).

[31] C. Marinach, M.-C. Papillon, and C. Pepe, Identification of binding media in works of art by gas chromatography-mass spectrometry, J. Cult. Herit. 5, 231-240 (2004).

[32] M. Strlic, B. Pihlar, L. Mauko, J. Kolar, S. Hocevar, and B. Ogorevc, A new electrode for microdetermination of paper $\mathrm{pH}$, Restaurator 26, 159-171 (2005).

[33] G. Bitossi, R. Giorgi, M. Mauro, B. Salvadori, and L. Dei, Spectroscopic techniques in cultural heritage conservation: A survey, Appl. Spectr. Rev. 40, 187228 (2005).

[34] J. Senvaitiene, A. Beganskiene, and A. Kareiva, Spectroscopic evaluation and characterization of different historical writing inks, Vibr. Spectrosc. 37, 61-67 (2005). 


\title{
NAUJAS METODOLOGINIS PRINCIPAS SENOVINIŲ RAŠALŲ ANALIZINIAM IDENTIFIKAVIMUI
}

\author{
J. Senvaitienè, A. Beganskienė, L. Salickaitė-Bunikienè, A. Kareiva
}

Vilniaus universitetas, Vilnius, Lietuva

\section{Santrauka}

Sukurtas naujas kokybinio senovinių rašalų identifikavimo metodologinis principas. Šiam tikslui buvo panaudoti IR, UV ir regimosios spektroskopijų bei kapiliarinès elektroforezès metodai. IR spektroskopiniai tyrimai atlikti, naudojant $\mathrm{KBr}$ tabletes arba ZnSe celę. Nustatyta, kad IR spektroskopijos variantas su KBr leidžia identifikuoti ịvairiu sudèčių istorinius rašalus, tačiau $\mathrm{ZnSe}$ varianto panaudojimas šiems tikslams yra nelabai tinkamas. Pirmą karta parodyta, kad UV ir regimosios spektroskopiju bei kapiliarinès elektroforezès metodai gali būti sèkmingai ir efektyviai pritaikomi nežinomos sudèties senovinio rašalo kokybinei sudèčiai ivertinti. Tyrimų rezultatai akivaizdžiai parodè, kad sukurtas metodologinis principas yra unikalus, greitas, paprastas ir patikimas. Nustatyta, kad tirtas nežinomas rašalas yra senovinis geležies galo riešutų rašalas. 